Federico Gana

\title{
Manchas de color
}

\section{LONDRES}

UÉ allá, ¿łe acuerdas? en la ciudad inmensa y famosa que envuelve en bruma su nieve, donde floreció nuestro amor.

¿Te acuerdas? En nuestro incierto paseo, dejamos atrás el gran río sobre cuyas aguas oscuras y silenciosas reverberaban las llamas inquietas de los faroles como las chispas de una fragua enorme y lantástica. En aquel anochecer de invierno tú murmuraste a mi oído con una voz perfumada de amor, estrechando mi brazo tembloroso contra tu corazón:

- Huyamos muy lejos, no sé adónde. Y como poseídos de un vértigo, marchamos rápidamente un instante por las callejuelas oscuras y pobres de aquella ciudad extranjera.

Después, fatigados, tristes, regresamos.

iY esa ha sido toda nuestra historia!

\section{LA VIRGEN INGLESA}

Sobre mis rodillas cae el dulce peso de tu cuerpo inmaculado.

En tu cabellera oscura hay un perfume fresco y matinal:

Inclinas sobre mi pecho tu pálida frente y hablas de aquel amor, de aquella ausencia, mientras yo, octogenario joven, paso mis miradas por esas cartas de amor de un niño.

El navio se balancea voluptuosamente sobre el gran lecho azul y vaporoso del mar.

Acaricio tus trenzas negras, mientras me descubres envanecida los secretos de tu corazón. 


\section{SOMBRA}

¡Ya no será posible que vuelvan los días buenos!

Las ilusiones ardientes de la pubertad, el triste florecimiento del corazón, en las horas de amor de los veinte años, se han ido. Sólo el fantasma pálido de un ideal de gloria desvanecido me acompaña por el camino sombrio. Y allí, muy cerca, veo alzarse una cruz negra bajo el cielo nebuloso.

Oh, cruz de muerte, tú no me haces temblar!; antes bien, contemplo con ternura tus tristes brazos en el horizonte helado. Siento ya en mi alma una fría mano que me arrastra dulcemente, mis ojos se abren con fatiga a la luz del día y mi corazón se ha cerrado. Y marcho siempre resignado con mi destino.

¡Ya no será posible que vuelvan los días buenos!

\section{LOS CAMINOS}

Los caminos de la tierra están manchados de sangre y el hombre, en su desamparo, lanza un grito de espanto que sube hasta lo alto.

Es en vano que los niños sonrían, es en vano que la luna inocente se alce tras de los pinos y de los cipreses. Ellos nada pueden contra el mal. Esa faz de plata que alumbra los negros follajes sólo trae una sonrisa triste a mi boca convulsa.

\section{MADRIGAL}

Cristina, eres variable como el tiempo inseguro. Ya brilla el sol, ya los cielos se nublan; pero tu juventud, tu belleza, ilumina los campos, las nubes y los cielos. Mi corazón aun guarda el resplandor radiante de tus ojos alegres. $\mathrm{Y}$ sigues siempre riendo hasta que el mundo triste te doblegue $y$ te ahogue entre sus brazos fríos.

FEDERICO GANA. 